\title{
From social networking and democratic activity to the efficacy of e-Government: Macro and micro perspectives
}

As my title for this editorial suggests, this edition provides new research findings in two spheres of profound interest to this journal and its readers: those of the gathering significance of social media to democratic engagements on the one hand, and of how to view and evaluate e-government in the contemporary state, on the other. In some respects these topics are coming more and more into the mainstream of democratic and governmental conversations, including those of academics. And so it should be. Information Polity is dedicated to enlarging discussion of these sorts and is firmly of the view that papers published between its covers are more and more what should be viewed as centre-ground rather than peripheral. Old ways of seeing, ones that miss the detail of informational and communications analysis, are increasingly found wanting. If we are to explain, analyse and even propose changes in the $21^{\text {st }}$ century polity then we need to understand the ways in which information flow and communication are changing. All five papers published here contribute richly to that necessary core of understanding.

In assembling the papers for this edition I was presented with a choice. Should I begin with three papers that offer new insights in the field of e-government or should I begin with the two papers that offer research findings on the use of social media in contemporary democracy? I have chosen the latter, but only because the first of these papers concerns the activities of what many would consider the fountainhead of democracy, that of parliament. As scholars we need to know a lot more than we do about how parliaments operate, as well as about other developments in the democratic sphere. The first two papers provide insights in these respects. Had I chosen to lead with the other three papers then I would be arguing something very similar from an 'egovernment' perspective. But, the parliamentary point held sway on this occasion.

The first paper in this edition raises major considerations for democratic practise and is from Cristina Leston-Bandeira and David Bender from the School of Politics, Philosophy and International Studies at the University of Hull, UK. Their research question is 'How deeply are parliaments engaging on social media?' The authors have used Facebook and Twitter feeds, as well as interview data, to examine social media activity in five European parliaments. The authors emphasise the late arrival of parliaments into the world of social media, their current engagement and the vulnerabilities that arise from engagement with such immediate and active [and possibly hostile] media. It is perhaps this latter point that explains why most parliamentary social networking activity is limited to business reporting rather than deeper forms of engagement with the public. The article has much to commend it including its specific findings. I would draw readers' attention to section 3 in particular. Here, under the question 'Do social media fit parliaments?', the authors provide an excellent review of the literature and the arguments that appertain in respect how a parliament qua parliament can, and most importantly, should engage with public debate. 
What we need to know more about in these respects is how political parties view this constitutional conundrum. If parliaments are the apex of constitutional democracy then deep public engagement should follow, it would seem. If, however, they are democratic cyphers because of the powerful political party memberships and government office-holders by which they are comprised, then public engagement by them will be treated with circumspection by these parties and is likely to be curtailed. Once again, as we have seen with other new media studies, existing practises and institutions are both potentially and actually challenged fundamentally. More work for review, of this kind, will be welcomed at Information Polity, including consideration of the appropriate role of parliaments in the social media era.

The second of these papers on social media in democratic settings is jointly from Signe Bock Segaard of the Institute for Social Research in Oslo, Norway and Jeppe Agger Nielsen from the Department of Political Science at Aalborg, Denmark. Their paper examines the blogs of candidates in 12 municipalities during the 2011 Norwegian local election campaigns, looking at the extent of political communication involved, whether interactive or 'one-way'. It is here that the authors expose a situation not dissimilar from that discussed in the first paper above; that "most communication consists of one-way information dissemination with little actual exchange of information". The authors also draw attention to what they call a 'paradox' deriving from their research findings. Whilst the declared intention of candidates is to 'connect' with the electorate one of the main outcomes is networking amongst themselves.

The conceptual depth and strength of this paper emanates from the authors' concern to explore what they refer to as the 'democratic visions of social media and the Habermasian idea of the role of rationality in deliberative democracy'. This exploration is conjoined with an empirical investigation of the pragmatics of everyday political campaigning as candidates compete for votes. Does deliberative vision, or does pragmatic politics prevail as candidates engage using social media during an election? In discussing the subtleties of this question the authors adduce much rich data from their study and reach intriguing and nuanced judgments about what they have found.

I turn now to three excellent papers on aspects of e-government. Each of these papers offers new findings and analysis on vitally important questions, thereby demonstrating that the scholarly community continues to offer insights of crucial importance to those working in government. Moreover, the first of these papers won the EGPA-IOS Press annual prize awarded to the best paper at the annual EGPA conference. This paper, from Esther Ruiz Ben from the Technical University, Berlin and Rene Meier and Tino Schuppan from the e-Government Competence Centre at Potsdam and looks at the hugely important issue of employee resistance to change in the context of governmental attempts at organisational transformation through the application of ICTs. They offer a critique of the existing 'Technology Acceptance Model' for analysing situations into which new technologies are being introduced, arguing that the model must be broadened if it is to capture factors not presently included but which offer rich explanation for resistance. In particular these authors find that the intrinsic quality of information circulated in the organisation about the proposed transformation, as well as the medium through which it is circulated [eg face to face, email etc], have statistically significant consequences for levels of employee resistance. On this latter point the authors call for more research on what might be the optimal 'diffusion channel' for informing and communicating with employees about transformational change.

The second of these papers on e-government looks at a relationship that has drawn insufficient attention by scholars up to this point. In their paper, Maddalena Sorrentino and Marco de Marco, respectively from Milan and Marconi universities in Italy, examine, in an Italian context, the relationship between the stimulation of e-government activity and deep economic crisis. They ask to what extent we find a new stimulus for e-government solutions occurring in a country seeking to reduce public debt and spending and whether e-government can itself stimulate economic growth. They conclude however that 
policymakers over-emphasise the cost reduction side of the 'austerity agenda' thereby failing to see egovernment as having transformational potential that could be a vital factor in driving economic growth. Policymakers' vision may narrow in times of economic hardship, it seems, with them preferring the safe ground of small scale changes in public services delivery to more transformational goals that might liberate new economic resources and stimulate growth. There may be a link here between this paper and that of Meier, Schuppan and Ben. Is there a resistance to profound change that can only be reduced if effective communications are established and developed between those proposing change and those who will be on its 'receiving end'? As Editor, I found this Italian paper particularly stimulating in that in takes on a big 'whole of government' theme, as well as a major economic situation, and seeks to link the two. I will welcome more work of this kind. If readers are interested in this subject then I would ask them to develop a 'conversation' with the authors of this paper.

Finally, our third e-government paper also takes on a major theme for this field, adding new thinking to the way in which evaluation of e-government projects takes place. This paper, from Tina Jukic, Mirko Vintar and Joze Bencima of the Faculty of Administration at Ljubljana, Slovenia looks in particular at the benefit to be gained from ex-ante evaluation of e-government projects over and above that to be gained from ex-post evaluation. Their starting point lies in the argument that many e-government projects are launched without sufficient attention to their evaluation. Imitation and lobbying may well explain how many e-government projects are undertaken rather than more rational calculation of likely successful outcomes. Such general lack of formal project planning may well explain the many failures with which the field of e-government is littered. These authors argue for much tighter project planning as well as for better assessment methods for forms of evaluation including ex-ante evaluation. Little has been done, they argue, that is convincing about these evaluative methods. In their paper the authors show that evaluation does have a statistically significant impact on project success, a finding that I trust the authors will be able to disseminate widely to those in public administration who are responsible for e-government project management.

JA Taylor, November, 2013. Editor-in-Chief, Information Polity. E-mail: jta@gcal.ac.uk 